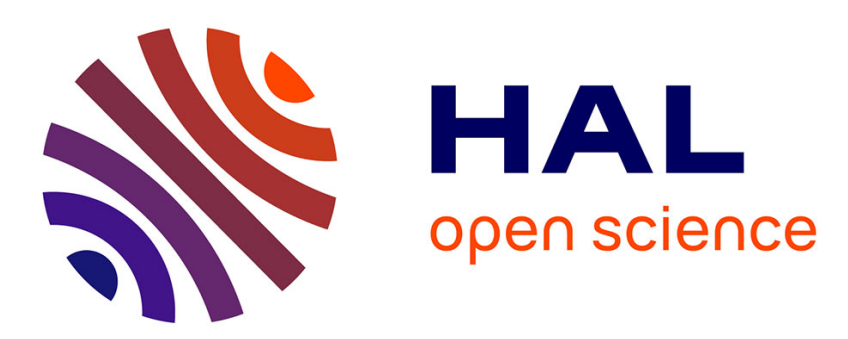

\title{
Probing intermediate process and active intermediate by positronium
}

Y. Wang, H. Cao, Y. Guo

\section{To cite this version:}

Y. Wang, H. Cao, Y. Guo. Probing intermediate process and active intermediate by positronium. Journal de Physique IV Proceedings, 1993, 03 (C4), pp.C4-99-C4-104. 10.1051/jp4:1993411 . jpa00251454

\section{HAL Id: jpa-00251454 https://hal.science/jpa-00251454}

Submitted on 1 Jan 1993

HAL is a multi-disciplinary open access archive for the deposit and dissemination of scientific research documents, whether they are published or not. The documents may come from teaching and research institutions in France or abroad, or from public or private research centers.
L'archive ouverte pluridisciplinaire HAL, est destinée au dépôt et à la diffusion de documents scientifiques de niveau recherche, publiés ou non, émanant des établissements d'enseignement et de recherche français ou étrangers, des laboratoires publics ou privés. 


\title{
Probing intermediate process and active intermediate by positronium
}

\author{
Y.Y. WANG, H.M. CAO and Y.H. GUO \\ Institute of High Energy Physics, Academia Sinica of China, P.O. Box 2732, Beijing 100080, China
}

\section{ABSTRACT}

A synthesis reaction of catalyst, olefin complex of rhodium, was chosen to explore the feasibility of probing active intermediate and intermediate process by positronium:

$$
2 \mathrm{RhCl}_{3} 3 \mathrm{H}_{2} \mathrm{O}+6 \mathrm{C}_{2} \mathrm{H}_{4} \rightarrow 2\left[\left(\mathrm{C}_{2} \mathrm{H}_{4}\right)_{2} \mathrm{RhCl}\right]_{2}+4 \mathrm{HCl}+2 \mathrm{CH}_{3} \mathrm{CHO}+4 \mathrm{H}_{2} \mathrm{O}
$$

Three different initial concentrations of $\mathrm{Rh}(\mathrm{III}), 7.6 \times 10^{-3}, 3.8 \times 10^{-2}$ and $4.5 \times 10^{-2} \mathrm{M}$ were sampled. The relations between positronium lifetime $\tau_{3}$, intensity $I_{3}$ and the concentration of Rh(III), ethylene, as well as of the products were determined. The $\mathrm{k}_{\mathrm{obs}}$ of the reaction between positronium and $\mathrm{Rh}$ (III) was obtained to be $4.51 \times 10^{9} \mathrm{M}^{-1} \mathrm{~s}^{-1}$.

On the basis of the yield of product $\left[\left(\mathrm{C}_{2} \mathrm{H}_{4}\right)_{2} \mathrm{RhCl}\right]_{2}$ given in reference[1], the reaction rate constant was calculated to be $0.152 \mathrm{~h}^{-1}$ for first-order reaction and $1.776 \mathrm{~h}^{-1}$ for second-order. Using these two constants and the measured relation between $\tau_{3}$ and $\mathrm{Rh}(\mathrm{III})$ concentration, according to the equations $\ln \mathrm{C}=\ln _{0}-\mathrm{k}_{\mathrm{t}} \mathrm{t}$ and $1 / \mathrm{C}=1 / \mathrm{C}_{0}+\mathrm{k}_{\mathrm{II}} \mathrm{t}$, the theoretical relation between $\tau_{3}$ and reaction time $\mathrm{t}$ for first-order and second-order reaction respectively were calculated. However, both the measured values of lifetime $\tau_{3}$ and intensity $I_{3}$ obviously departed from the calculated values, no matter it's first or second-order. The extra reduces of $\tau_{3}$ and $\mathrm{I}_{3}$ were discussed and attributed to the presence of an active intermediate $\mathrm{Rh}(\mathrm{II})$. In the light of the change tendency of $\tau_{3}$ with $t$, this synthesis process approximated to a second-order reaction. It showed that a dipolymer $\left[\left(\mathrm{C}_{2} \mathrm{H}_{4}\right)\left(\mathrm{CH}_{2}-\mathrm{CH}_{2}-\right)\right.$ $\mathrm{RhCl}_{2} \mathrm{I}_{2}$ might be formed in the first step of the synthesis.

$\mathrm{OH}$

\section{INTRODUCTION}

We have investigated the Redox reaction of unusual valence Ni(IV) and RSH by positronium [2]. In the light of the extra reduce of positronium lifetime $\tau_{3}$ and intensity $I_{3}$, we have suggested the presence of an active intermediate $\mathrm{Ni}(\mathrm{III})$ and discussed the way of investigating intermediate process and active intermediate by positronium. In order to 
make further investigation, in this paper a very useful preparative reaction of catalyst, rhodium compound $\left[\left(\mathrm{C}_{2} \mathrm{H}_{4}\right)_{2} \mathrm{RhCl}\right]_{2}$, was chosen to probe active intermediate and to explore intermediate process by positronium. $\mathrm{Rh}_{2}(\mathrm{CO})_{4} \mathrm{Cl}_{2}$ is a superior catalyst in many organic syntheses which involve reactions of olefins. The synthesis of dichlorotetracarbonyldirhodium, $\left[\left(\mathrm{C}_{2} \mathrm{H}_{4}\right)_{2} \mathrm{RhCl}\right]_{2}$, from rhodium trichloride is a basic reaction for preparing $\mathrm{Rh}_{2}(\mathrm{CO})_{2} \mathrm{Cl}_{2}$.

$$
2 \mathrm{RhCl}_{3} \cdot 3 \mathrm{H}_{2} \mathrm{O}+6 \mathrm{C}_{2} \mathrm{H}_{4} \rightarrow\left(\mathrm{C}_{2} \mathrm{H}_{4}\right)_{2} \mathrm{Rh}_{\mathrm{Cl}^{\prime}}^{\mathrm{C}} \stackrel{\mathrm{Cl}}{\mathrm{R} h}\left(\mathrm{C}_{2} \mathrm{H}_{4}\right)_{2}+4 \mathrm{HCl}+2 \mathrm{CH}_{3} \mathrm{CHO}+4 \mathrm{H}_{2} \mathrm{O}
$$

$\mathrm{Rh}(\mathrm{III})$ is reduced to $\mathrm{Rh}(\mathrm{I})$ by bubbling ethylene in methanolic solution at room temperature. This reaction is important, but its mechanism is not yet explained clearly. There are two possible ways reducing Rh(III) to $\mathrm{Rh}(\mathrm{I})$ by ethylene, either directly reducing to $\mathrm{Rh}(\mathrm{I})$ by two electrons transfer or successively reducing to $\mathrm{Rh}(\mathrm{II})$ and $\mathrm{Rh}(\mathrm{I})$ by one electron transfer. Detecting intermediate is one of the best way to understand a multistep reaction mechanism, however, the proposed intermediates are usually extremely reactive, shortlived, and difficult to study independently. Considering the positronium has high chemical reactivity and very short quenching lifetime, it should easily perturbed by reactive intermediates. It will result in the abnormal changes of $\tau_{3}$ and $\mathrm{I}_{3}$. The changes are related to characters of intermediate. One can generally state that all interactions of positronium with matter lead to shortening its lifetime. The extent of change will depend on strength of the interaction. The changes of $\mathrm{I}_{3}$ mainly relate on the intermediate to be the electronacceptor or electron-doner, the former inhibits positronium formation and leads to decrease of $\mathrm{I}_{3}$.

As a probe, positronium usually does not destroy and disturb the investigated systems. Measurements can be made in reaction vessel, so that sampling with its attendant errors can be eliminated. It is also possible to record the change in lifetime and intensity of positronium automatically and continuously. The relation between positronium lifetime and concentrations of reactants and of products can be separately determined. The departure of these relations during reaction can suggest the presence of active intermediate and intermediate process, which give us some information of the reaction mechanism.

\section{EXPERIMENTS AND RESULTS}

For each experiment $5 \mathrm{ml}$ measured solution was put into a nickel-plating stainless steal vessel. In order to keep a shorter distance between two detectors, the vessel was made in a flat shape, its width is $7 \mathrm{~mm}$ only and wall thickness $0.3 \mathrm{~mm}$. The ${ }^{22} \mathrm{Na}$ source of about $7 \mu \mathrm{ci}$ was sealed in two pieces of $5 \mu$ Kapton foil with a special glue. It was propped up with a frame and put in center of vessel. The source effect was estimated about $10 \%$. No any activity leak was found standing the test of long time. For decreasing contact with air, the vessel was sealed in a small bag of plastic foil. The resolution of lifetime spectrometer is $410 \mathrm{ps}$, the efficiency is high.

\section{Removing oxygen from solution by high pure nitrogen}

The investigated reaction took place in the methanolic solution with $6 \% \mathrm{H}_{2} \mathrm{O}$, so 
all the contrast measurements were aimed at such component solution.

We have checked the effects of oxygen on $\tau_{3}$ and $I_{3}$ in such solution. In this work the solvents, methanol and $6 \% \mathrm{H}_{2} \mathrm{O}$ were treated with bubbling high pure $(>99.99 \%)$ nitrogen for one or half an hour to remove oxygen. The values of $\tau_{3}$ respectively are $3.000 \mathrm{~ns}$ and $3.286 \mathrm{~ns}$ in methanol with $6 \% \mathrm{H}_{2} \mathrm{O}$ before and after degassing. They are consistent with the values given in reference[3,4], and also with the value extrapolated the relation between $\tau_{3}$ and concentration $\mathrm{C}$ to zero. It shows that the influence of remained oxygen is negligible after treatment with nitrogen.

\section{Determination of relation between $\tau_{3}$ and concentration of $\mathrm{RhCl}_{3}$}

$\mathrm{RhCl}_{3}$ is the major reactant in the investigated reaction. Its concentration, $\mathrm{C}$, gradually decreases with reaction time $t$. For probing this reaction by positronium, we have to understand the effects of $\mathrm{RhCl}_{3}$ on positronium, namely, the relation between $\tau_{3}$, $\mathrm{I}_{3}$ and concentration of $\mathrm{RhCl}_{3}$. The measured solutions with different concentration of $\mathrm{RhCl}_{3}$ were prepared by dissolving rhodium trichloride trihydrate in a few water, then diluted to the necessary concentration by degassed methanol. The results showed that it seemed a linear relation between $\tau_{3}$ and $\mathrm{C}$ as the concentration lower than $5 \times 10^{-2} \mathrm{M}$ and between $\mathrm{I}_{3}$ and $\mathrm{C}$ as the concentration lower than $3 \times 10^{-2} \mathrm{M}$.

$$
\begin{aligned}
& \tau_{3}(\mathrm{~ns})=(3.237 \pm 0.008)-(31.89 \pm 0.44) \mathrm{C} \\
& \mathrm{I}_{3}(\%)=(18.59 \pm 0.08)-(130.1 \pm 7.4) \mathrm{C}
\end{aligned}
$$

A satisfactory linear relation between ${ }_{3}$ and $\mathrm{C}$ was obtained by least square fit (Fig.1).

$$
\lambda_{3}\left(\mathrm{~ns}^{-1}\right)=(0.304 \pm 0.001)+(4.51 \pm 0.09) \mathrm{C}
$$

According to $\mathrm{k}_{\mathrm{obs}}=\left(\lambda_{3}-\lambda_{\mathrm{p}}\right) / \mathrm{C}$, where $\lambda_{\mathrm{p}}$ is the reciprocal of positronium lifetime in solvent, the rate constant of reaction between positronium and $\mathrm{Rh}$ (III) was obtained to be $4.51 \times 10^{9} \mathrm{M}^{-1} \mathrm{~s}^{-1}$.

\section{Influences of other components in the reaction system on positronium}

Besides $\mathrm{RhCl}_{3}$ the other reactant in this synthesis reaction is ethylene. Because of the continuous bubbling ethylene, its concentration can be considered constant in the system. The measured value of $\tau_{3}$ is $3.318, \mathrm{I}_{3}$ is $17.389 \%$ in methanol saturated with ethylene, thus suggesting that the ethylene is irrelevant to positronium. Besides the insoluble product $\left[\left(\mathrm{C}_{2} \mathrm{H}_{4}\right)_{2} \mathrm{RhCl}\right]_{2}$, the products also include $\mathrm{CH}_{3} \mathrm{CHO}$ and $\mathrm{HCl}$. The concentration of $\mathrm{HCl}$ is very limited, it could not affect positronium. The $\tau_{3}$ and $\mathrm{I}_{3}$ were measured in methanolic solution of $8 \times 10^{-2} \mathrm{M} \mathrm{CH}_{3} \mathrm{CHO}$ to be $3.291 \mathrm{~ns}$ and close on $18.0 \%$ respective1y. No effect was found too. These results indicated that the other components did not affect positronium lifetime and intensity in this system except $\mathrm{RhCl}_{3}$.

\section{Observation of relation between $\tau_{3}$ and reaction time $t$}

The positronium lifetimes $\tau_{3}$ and intensities $I_{3}$ were measured along with the time $t$ of bubbling ethylene in three solutions with different $\mathrm{RhCl}_{3}$ initial concentrations $7.6 \times 10^{-3}$ $\mathrm{M}, 3.8 \times 10^{-2} \mathrm{M}$ and $4.5 \times 10^{-2} \mathrm{M}$ respectively. For each sampling $5 \mathrm{ml}$ initial solution was transferred to the vessel, then stirred by continuous bubbling ethylene with an inserted syringe needle. The lifetime spectrum was measured every one hour, and accumulated to $7 \times 10^{5}$ counts for each measurement. The experimental results are show in Fig2 - Fig4. 


\section{DISCUSSION}

On the basis of $\left[\left(\mathrm{C}_{2} \mathrm{H}_{4}\right)_{2} \mathrm{RhCl}\right]_{2}$ yield given in reference[1], bubbling ethylene for 7 hours produced $65.4 \%\left[\left(\mathrm{C}_{2} \mathrm{H}_{4}\right)_{2} \mathrm{RhCl}\right]_{2}$, we respectively estimated the rate constant to be $0.152 \mathrm{~h}^{-1}$ and $1.776 \mathrm{~h}^{-1} \mathrm{M}^{-1}$ for first-order and second-order reaction. Using these two rate constants and the equation of concentration $\mathrm{C}$ and reaction time $\mathrm{t}$ for first-order and second-order reaction

$$
\begin{aligned}
& \ln C=\ln C_{0}-k_{1} t \quad \text { (first-order reaction) } \\
& 1 / \mathrm{C}=1 / \mathrm{C}_{0}+\mathrm{k}_{\mathrm{HI}} \mathrm{t} \quad \text { (second-order reaction) }
\end{aligned}
$$

we calculated the theoretical values of $\mathrm{Rh}$ (III) concentration as a function of reaction time t. Fig2a,3a showed respectively the relations between $\mathrm{C}$ and $\mathrm{t}$ in two solutions with initial $\mathrm{Rh}$ (III) concentration $4.5 \times 10^{-2} \mathrm{M}$ and $3.8 \times 10^{-2} \mathrm{M}$. According to equations $\tau_{3}=3.237-31.89$ $\mathrm{C}$ and $\mathrm{I}_{3}=18.59-130.1 \mathrm{C}$, these relations can be alternated to $\tau_{3}$ against $\mathrm{t}(\mathrm{Fig} 2 \mathrm{~b}, 3 \mathrm{~b})$ and $\mathrm{I}_{3}$ against $\mathrm{t}($ Fig4).

Fig. 2-4 show that as the reaction going on, the measured relations between $\tau_{3}$ and $t, C$ and $t$, as well as $I_{3}$ and $t$ departed dramatically from the theoretic relations. Both the $\tau_{3}$ and $\mathrm{I}_{3}$ were obviously lower than expected, whereas it looked as if the concentrations of Rh(III) to be higher than the proper.The similar result was obtained in the solution of $7.6 \times 10^{-3} \mathrm{M}$.

The departure gradually decreased in the later stage of reaction, and $\tau_{3}$ approached to the values of the second-order reaction. It suggested that some active intermediates are present in the reaction process. They led to positronium lifetime shortening and the formation to be inhibited. The proposed intermediate should be a complex of two-valent rhodi$\mathrm{um}$, in other words the synthesis from $\mathrm{RhCl}_{3}$ to $\left[\left(\mathrm{C}_{2} \mathrm{H}_{4}\right)_{2} \mathrm{RhCl}\right]_{2}$ included two steps of oneelectron transfer:

$$
\operatorname{Rh}(\mathrm{III}) \stackrel{\mathrm{k}_{1}}{\rightarrow} \mathrm{Rh}(\mathrm{II}) \stackrel{\mathrm{k}_{2}}{\rightarrow} \mathrm{Rh}(\mathrm{I})
$$

In view of the tendency of $\tau_{3}$ variation, the reaction seemed to be second-order. Judging from the electron structure of $\mathrm{Rh}(\mathrm{II})$, the Rh(II) complex with five coodinations using the $\mathrm{dsp}^{3}$ mixed orbit may be more reasonable. In the first step of reaction two molecules of $\mathrm{Rh}(\mathrm{III})$ joined and were reduced to form a bridge dipolymer $\left[\left(\mathrm{C}_{2} \mathrm{H}_{4}\right)\left(\mathrm{CH}_{2}-\mathrm{CH}_{2}-\right) \mathrm{RhCl}_{2}\right]_{2}$.

Such unstable intermediate should be a strong oxidizing agent for positronium and resulted in a further shortening of $\tau_{3}$ and in the departure of relation between $\tau_{3}$ and $t$.

As the second-order reaction requires the collision of two Rh(III) molecules, the reaction probability is low. To a certain extent it reflected this synthesis reaction taking such a long time. The fact that the measured values of $\tau_{3}$ and $\mathrm{I}_{3}$ during reaction were much shorter and lower than the calculated values also showed the rate constant $k_{2}$ to be not very high. $\mathrm{Rh}(\mathrm{II})$ is an unstable state and more reactive, but reducing to $\mathrm{Rh}(\mathrm{I})$ to form $\left[\left(\mathrm{C}_{2} \mathrm{H}_{4}\right)_{2} \mathrm{RhCl}\right]_{2}$ is not very fast. So that the intermediate $\mathrm{Rh}(\mathrm{II})$ could be accumulated a considerable amount to cause the extra drop of $\tau_{3}$ and $\mathrm{I}_{3}$. According to the maximum departure of $\tau_{3}$ from the theoretical relation between $\tau_{3}$ and $t$ in the system with initial $\mathrm{RhCl}_{3}$ concentration $3.8 \times 10^{-2} \mathrm{M}$, we made a rough estimate of $\mathrm{k}_{2}$ using the equation of 
second-order reaction.

Consider the concentration of ethylene, $\left[\mathrm{C}_{2} \mathrm{H}_{4}\right]$ to be constant in our experiment

$$
\begin{aligned}
& \mathrm{d}[\mathrm{Rh}(\mathrm{II})] / \mathrm{dt}=\mathrm{k}_{1}[\mathrm{Rh}(\mathrm{III})]^{2}-\mathrm{k}_{2}[\mathrm{Rh}(\mathrm{II})] \\
& {[\mathrm{Rh}(\mathrm{II})]_{\max }=\left(\mathrm{k}_{1} / \mathrm{k}_{2}\right)[\mathrm{Rh}(\mathrm{III})]^{2}} \\
& \text { with } \Delta \lambda_{\max }=\mathrm{k}_{\mathrm{obs}}[\mathrm{Rh}(\mathrm{II})]_{\max } \\
& {[\mathrm{Rh}(\mathrm{II})]_{\max }=\Delta \lambda_{\max } / \mathrm{k}_{\mathrm{obs}}} \\
& \mathrm{k}_{2}=\mathrm{k}_{1} \mathrm{k}_{\mathrm{obs}}[\mathrm{Rh}(\mathrm{III})]^{2} / \Delta \lambda_{\max }
\end{aligned}
$$

$\mathrm{k}_{1}$ took $1.776 \mathrm{~h}^{-1} \mathrm{M}^{-1}$, suppose the rate constant of $\mathrm{Rh}(\mathrm{II})$ and positronium, $\mathrm{k}_{\mathrm{obs}}$, reaching $10^{11} \mathrm{M}^{-1} \mathrm{~s}^{-1}$. The measured $\Delta \lambda_{\max }$ took the value of $3.4 \times 10^{7} \mathrm{~s}^{-1}$ at $\mathrm{t}$ to be 11 th hour. The concentration of $\mathrm{Rh}(\mathrm{III})$ should be $2.18 \times 10^{-2}$ at this time. Thus, $\mathrm{k}_{2}$ was obtained to be $2.5 \mathrm{~h}^{-1}$.

The value of $\mathrm{I}_{3}$ raised with reaction time $t$, but it obviously departed from the theoretic values even in the later stage of reaction. It indicated that the intermediate strongly inhibited positronium formation. Even if its concentration is very low, its effect is still observable. Using an empirical equation describing "total inhibition of positronium formation" $I_{3}(c) / I_{3}(0)=1 /(1+K C)[5]$, in principle the inhibition constant of the intermediate Rh(II) can be suggested by taking an estimated value of Rh(II) concentration.

On the basis of the experimental results we think that probing fast intermediate processes and active intermediates in slower reaction by positronium is valid and feasible.

Acknowledge

Authors are indebted to professor Han De Gung at Chemistry Department of Peking University for valuable suggestion and discussion.

This work is supported by National Nature Science Foundation.

\section{Reference}

[1] R.Cramer, Inorg. Synth., 15,14(1974)

[2] Y.Y.Wang,Z.P.Wang,L.L.Yang, Y.H.Guo and M.R.Huang,Materials Science Forum Vols. 105-110,1804(1992)

[3] R.M.Singru, K.B.Lal and S.J.Tao, Atomic Data and Nuclear Data Tables, V.17, 4, 367(1976)

[4] "Chemical Reactions Between Oxygen and Positronium in Solutions", M.S.Thesis by GuangMing Zhou, University of Missouri-Kansas City, U.S.A.(1992)

[5] G.Duplatre, J.Ch.Abbe, A.G.Maddock and A.Haessler,J.Chem.Phys., 72,89(1980) 


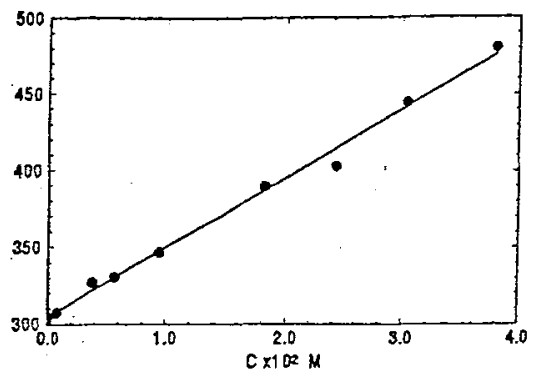

Fig. $\lambda_{3}$ vs $\mathrm{FhCl}_{3}$ Concentration

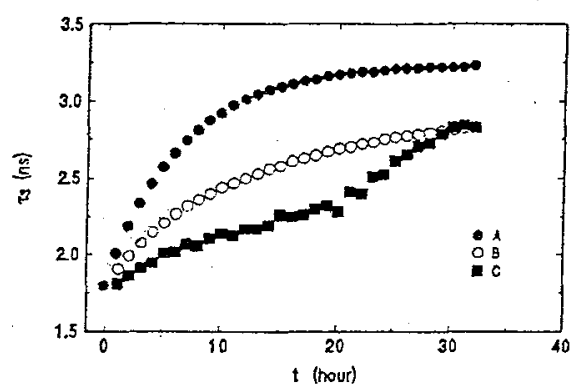

Fig.2b $\tau_{3}$ vs Reaction time

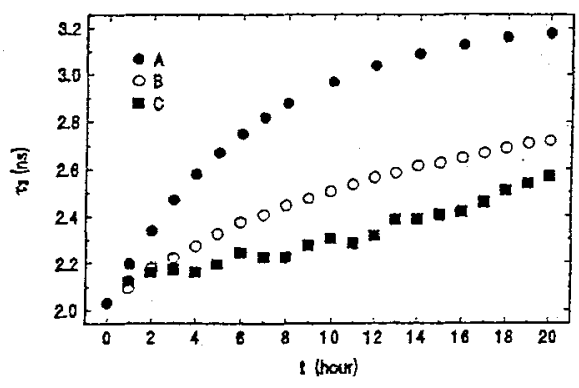

Fig.3b $\tau_{3}$ ys Reaction time

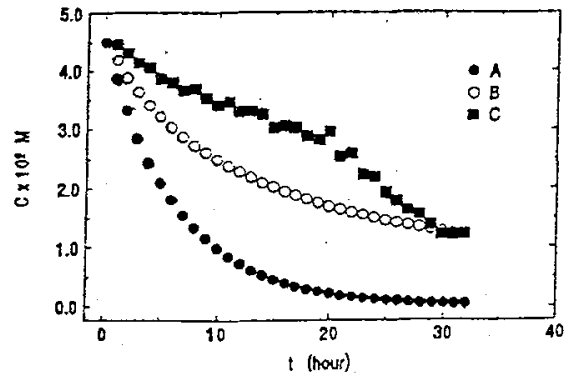

Fig.2a Concentration vs Reaction time

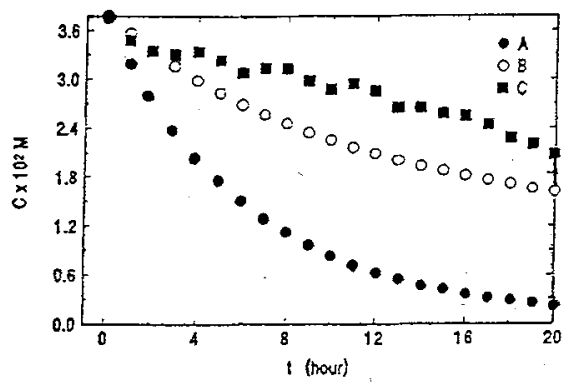

Fig.3a Concentration vs Reaction time

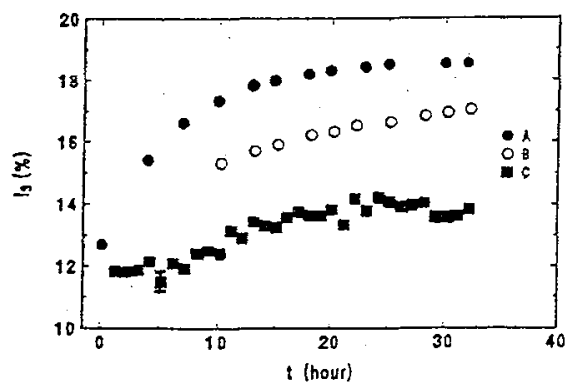

Fig.4 is vs Reaction time

\section{Figure Caption}

Fig. 2a,2b and Fig. 4 - The initial concentration of $\mathrm{RhCl}_{3} \mathrm{C}_{0}=4.5^{*} 10^{-2} \mathrm{M}$

Fig. $3 \mathrm{a}, 3 \mathrm{~b}-$ The initial concentration of $\mathrm{RhCl}_{3} \mathrm{C}_{0}=3.8 * 10^{-2}$
A - theoretic curve (first-order reaction)
$\mathrm{B}$ - theoretic curve (second-order reaction)
$\mathrm{C}$ - experiment curve 